\title{
EARNINGS MANAGEMENT AND NEW LISTINGS: EVIDENCE FROM VIETNAM
}

\author{
Anh Huu Nguyen and Chi Thi Duong* \\ School of Accounting and Auditing, National Economics University, Vietnam \\ "Corresponding author: duongchi@neu.edu.vn
}

Published online: 1 December 2021

To cite this article: Nguyen, A. H., \& Duong, C. T. (2021). Earnings management and new listings: Evidence from Vietnam. Asian Academy of Management Journal, 26(2), 27-51. https://doi.org/10.21315/aamj2021.26.2.2

To link to this article: https://doi.org/10.21315/aamj2021.26.2.2

\begin{abstract}
Earnings management around corporate events has been widely discussed in literature review which has shown mixed results. Furthermore, prior studies have extensively focused on earnings management around initial public offerings (IPOs) and seasoned equity offerings (SEOS), while less attention has been given to the listing event. Another motivation comes from the context of the undeveloped market. While earnings management has been widely discussed in developed countries, it is still limited in emerging countries in general and in Vietnam in particular, due to the lack of research on this phenomenon and the unique institutional feature and pre-listing profit requirement in Vietnam's stock market. This research is conducted to investigate the earnings management behaviour around listing event in Vietnam. The sample of this study consists of financial data from 189 newly listed companies on the Ho Chi Minh City Stock Exchange (HOSE) for the period of 2009-2017. Four cross-sectional models were used to estimate earnings management, including two total accruals-based models and two current accruals-based models. This research makes important contributions to the body of literature on Vietnam's stock market. First, this study provides empirical evidence suggesting a greater positive earnings management practice of newly listed firms in current accrual models than those in total accrual models. Second, the results from both parametric and non-parametric test statistics show that HOSE-listed firms present higher levels of earnings management in the year prior to the listing than those in post-listing year and two subsequent years after listing. Finally, new listing requirements in 2012 require the company's return on equity (ROE) in the most recent year to be at least 5\%. However, the paper finds no
\end{abstract}

(C) Asian Academy of Management and Penerbit Universiti Sains Malaysia, 2021. This work is licensed under the terms of the Creative Commons Attribution (CC BY) (http://creativecommons. org/licenses/by/4.0/). 
evidence to suggest that relative to all newly listed firms after the new profit requirement exhibit greater positive earnings management than that of firms listed before the change in pre-listing year.

Keywords: accounting accruals, earnings management, Ho Chi Minh City Stock Exchange, listing requirements, new listings

\section{INTRODUCTION}

Accounting principles allow managers to exercise considerable discretion over accruals, which creates flexibility in terms of exercising certain amount of judgement in preparing financial statements through choices of accounting and reporting methods, especially in new issuance events, which is known as a rich information asymmetry context. This behaviour is consistent with the earnings management definition suggested by Healy and Wahlen (1999, p. 368) as "managers use judgment in the financial reporting and in structuring transactions to alter financial reports to either mislead some stakeholders about the underlying economic performance of the company, or to influence contractual outcomes that depend on reported accounting numbers." Some studies have determined three events in which firms have incentives and possibilities to manipulate earnings before issuing shares via initial public offerings (IPOs), seasoned equity offerings (SEOs), or new listings. Several international studies have documented the existence of earnings management surrounding new issuance. Results of these studies illustrate the contrast among levels of accruals earnings management ranging from very aggressive (such as Aharony et al., 1993; DuCharme et al., 2004; Friedlan, 1994; Kao et al., 2009; Nuryaman, 2013; Rangan, 1998; Shivakumar, 2000; Teoh et al., 1998a, 1998b) to no earnings management (such as Armstrong et al., 2008; Ball \& Shivakumar, 2008; DuCharme et al., 2001; Premti, 2013) to no earnings management (such as DuCharme et al., 2001; Ball \& Shivakumar, 2008; Armstrong et al., 2008; Premti, 2013). Review of the earnings management around issuance of equity and new listings indicates that while earnings management during issuance of equity is fully documented, the study on accruals earnings management and new listings is not strong enough. While IPOs and SEOs are the types of equity issuance in which the shares of a firm are sold to investors with the main objective to raise capital, listing refers to an entrance of firms into a stock exchange and the transformation to publicly owned entities. Listing offers advantages to firms such as raising further capital, improving their reflectivity and reputation, having higher collateral value of the securities, and achieving better corporate practice and better liquidity of marketable securities. Firms must meet all the listing requirements set out by the governing bodies to be listed on the stock 
exchange. Hence, it would come as no surprise that managers of firms seeking a listing might inflate their earnings upward to satisfy all the listing requirements and induce optimistic expectations of investors (Charitou \& Louca, 2003; Eiman, 2013).

This study is motivated by several factors. Firstly, the studies on earnings management around corporate events have provided conflicting results. In addition, prior studies have extensively focused on earnings management around IPO and SEO, while little attention has been paid to the listing event. Therefore, further study is needed to provide a better understanding of earnings management around listing. Secondly, in the context of the undeveloped market, there is a lack of research on earnings management around the listing event, particularly in Vietnam. For more than 20 years, Vietnamese stock market has progressed from an early stage with weak form efficiency to more strongly established infrastructure that is playing an increasingly important role to Vietnamese economy in recent years. The Vietnamese stock market is closely supervised and regulated by four governing bodies, which induces profound impacts on market's performance. The Vietnamese stock market has undergone several development stages of legal frameworks, which have gradually been amended and improved both quantitatively and qualitatively to meet the changes of market environment and to improve the openness and transparency of the market. As a result, listing requirements provided by law and guiding documents have been modified several times with conditions such as capital adequacy, legality, capital structure, profitability, accounting practice, and information disclosures. However, the market still has a series of issues, such as shortage of policies and complicated legal framework (Nguyen \& Ian, 2003), low transparency, weak legal environment, and lack of regulatory coordination (Zingales, 2009), and the existence of market manipulation and herd behaviour (Vo \& Phan, 2016). The final motivation is related to Vietnam's unique legal system, accounting practice, and pre-listing profit requirement. It is believed that the efficiency of the legal system may affect the level of earnings management (Memis \& Cetenak, 2012). In Vietnam, the legal system is based on law dictionary. Therefore, the government has played a key role in the national accounting system. Taxes and fiscal policy maintain a certain influence on accounting. In addition, accounting standards influence the level of earnings management because different accounting standards provide different accounting choices (Goncharov \& Zimmermann, 2007). Many developing countries show the different approaches in applying their accounting systems towards the International Accounting Standards (IAS)/International Financial Reporting Standards (IFRS). While Mongolia has fully adopted IAS/IFRS, Singapore, India, Malaysia, Pakistan, and Thailand have adopted quite closely but with some significant modifications. 
As of today, Vietnam has a different experience as financial statements are prepared in accordance with Vietnam Accounting Standards (VAS) issued by the Ministry of Finance. VAS has been established based on the old version of IAS/IFRS with modifications to fit the Vietnam context but still lacks various updates from IFRS. In short, while IFRS is based on principles, VAS is mainly rules-based accounting. Vietnamese firms must comply with VAS and the accounting policies with a uniform chart of accounts and entries, preparation and presentation of financial statements, accounting documents and accounting records which can lead to a mismatch between the substance of transactions and accounting treatments, leaving a large discretionary margin for treatment of earnings. Moreover, Vietnam has been chosen for this study because of the presence of a unique pre-listing profit requirement in comparison with other countries in the region. Some countries in the region establish these standards which require firms to have a specific minimum amount of accumulated net profit in the last three fiscal years (even 3 to 5 years). For example, to get listed in the Main Market of Malaysia Stock Exchange, firms are required to report an uninterrupted profit after tax of three to five full fiscal years, with an aggregate of at least RM20 million; Main Board of the Philippine Stock Exchange requires the listing applicant to satisfy minimum cumulative consolidated earnings before interest, taxes, depreciation, and amortization (EBITDA), excluding nonrecurring items, of at least PHP50 million for three full fiscal years immediately preceding the application for listing and a minimum EBITDA of PHP10 million for each of the three fiscal years; for listing to the Stock Exchange of Thailand, the listing applicant must have an aggregate of at least THB50 million in net profits after tax in the last two to three fiscal years and a net profit in the most recent fiscal year of at least THB30 million. Vietnam shows a different experience with less stringent minimum listing requirements which require firms to have operating profit for only two consecutive years prior to listing and no accumulative loss. This unique institutional feature makes themselves as an excellent candidate to examine the earnings management around listing events in this undeveloped market.

To the best of our knowledge, this is the first study to examine the earnings management of newly listed firms in Vietnam by using real data collected from financial statements of listed firms on Ho Chi Minh City Stock Exchange (HOSE). Using a sample of 189 firms for the period from 2009 to 2017, this study investigates whether newly listed firms on HOSE manipulate their earnings upwards in pre-listing year and whether these firms engage more in earnings management in the year prior to listing than in post-listing years. 
The paper is structured as follows. Literature review and hypotheses are presented in the next section. This is followed by the introduction of the sample and methodology used for the study. Empirical results and analyses are then presented, with conclusion and suggestions for further research in the last section.

\section{LITERATURE REVIEW AND HYPOTHESIS DEVELOPMENT}

\section{HOSE}

The stock market in Vietnam is supervised and regulated by four governing bodies: (1) the National Assembly issues the law on securities; (2) the government performs the unified management of securities and securities market; (3) the Ministry of Finance is responsible for submitting strategies, planning and policies on securities and securities market and managing the State Securities Commission; and (4) State Securities Commission (SSC), an organisation under the Ministry of Finance, which responsible for exercising the State regulations on securities and securities market, supervising activities in securities market, and managing public services in securities market in accordance with applicable laws.

The stock market in Vietnam, which was officially established on 20 July 2000 as the Ho Chi Minh City Securities Trading Centre, is at a very nascent stage. To date, there are two securities trading centres established in Ho Chi Minh City and Hanoi. HOSE, which serves as the country's primary stock exchange, is the largest and most developed stock exchange in Vietnam. By the end of 2019, there were 378 companies listed on HOSE with the total market capitalisation of 3.29 quadrillion dong (equivalent to nearly $54.3 \%$ of GDP in 2019), accounting for $90 \%$ of the total market capitalisation in Vietnam's stock market (Ky Ngoc, 2020). Listed firms on HOSE are categorised into 11 sectors as follows: real estate, finance, consumer staples, industrials, utilities, materials, consumer discretionary, energy, information technology, healthcare, and communications services.

To be listed on HOSE, firms must meet specific listing requirements and follow the laws and regulations by the State (National Assembly, government, Ministry of Finance). In 2012, milestone changes in regulations were set out as indicated in Table 1. 
Table 1

The major changes in HOSE listing requirements

\begin{tabular}{|c|c|c|}
\hline Conditions & $\begin{array}{l}\text { Before } 15 \text { September } 2012 \\
\text { [The Government. (2007). } \\
\text { Decree No: } 14 \text { Detailing the } \\
\text { Implementation of a Number of } \\
\text { Articles of the Law on Securities] }\end{array}$ & $\begin{array}{l}\text { After } 15 \text { September } 2012 \\
\text { [The Government. (2012). Decree No: } \\
58 \text { Stipulating in Detail and Guiding } \\
\text { the Implementation of a Number of } \\
\text { Articles of the Securities Law and the } \\
\text { Law Amending and Supplementing a } \\
\text { Number of Articles of Securities Law] }\end{array}$ \\
\hline $\begin{array}{l}\text { Booked paid-up } \\
\text { charter capital } \\
\text { at the time of } \\
\text { registration for } \\
\text { listing }\end{array}$ & $\begin{array}{l}\text { From } 80 \text { billion dong (USD } 3.47 \\
\text { million) or more. This capital level } \\
\text { may be increased or reduced by } \\
30 \% \text { at most by the Ministry of } \\
\text { Finance (Prime Minister) }\end{array}$ & $\begin{array}{l}\text { From } 120 \text { billion dong (USD5.2 } \\
\text { million) or more, calculated at the } \\
\text { value recorded in the accounting } \\
\text { books }\end{array}$ \\
\hline \multirow[t]{2}{*}{ Profit condition } & \multicolumn{2}{|c|}{$\begin{array}{l}\text { - Having operating profit for two consecutive years prior to listing } \\
\text { registration year } \\
\text { - Suffering no accumulative loss by the year of listing registration }\end{array}$} \\
\hline & There is no requirement & $\begin{array}{l}\text { The return on equity ratio in } \\
\text { pre-listing year equals to at least } 5 \%\end{array}$ \\
\hline Debt & $\begin{array}{l}\text { Having no overdue debt not yet } \\
\text { backed by a provision according } \\
\text { to the provisions of law }\end{array}$ & $\begin{array}{l}\text { There is no overdue debt for more } \\
\text { than one year }\end{array}$ \\
\hline Shareholding & $\begin{array}{l}\text { Minimum of } 100 \text { shareholders } \\
\text { holding at least } 20 \% \text { of voting } \\
\text { shares other than major } \\
\text { shareholders }\end{array}$ & $\begin{array}{l}\text { Minimum of } 300 \text { shareholders holding } \\
\text { at least } 20 \% \text { of voting shares other } \\
\text { than major shareholders }\end{array}$ \\
\hline
\end{tabular}

Source: Research collection from the Decrees issued by Government (2007) and Government (2012)

Table 1 illustrates a timeline and conditions for changes to listing on HOSE for the period before and after 2012. A new set of listing requirements was issued in 2012 under Decree 58, which replaces Decree 14, introducing tougher listing conditions as shown in Table 1. Over a short-time span, the HOSE listing requirements have been modified. The conditions that require firms to be profitable in two consecutive years immediately preceding the year of listing and having no accumulated losses at the year of listing remain unchanged. Among the changes stipulated in Decree 58, the most significant change is to increase the minimum level of charter capital and the requirement for return on equity (ROE) in the most recent years prior to listing to be at minimum 5\%. Consequently, approximately $34 \%$ of firms currently listed on HOSE became unqualified for listing under the new regulations (in which 90 firms having ROE below 5\% and 30 firms having charter capital of 
less than 120 billion dong). However, the new decree has a transitional provision that allows companies listed before 15 September 2012 to maintain their stocks on the current stock exchange ("New regulations on securities investment," 2012).

Subsequently, the number of newly listed firms on HOSE has significantly decreased over years which fell from 133 firms for three years before to 33 firms for three years after the new decree. Since the listing conditions restricted the number of firms listed on the HOSE, firms have strong incentives to manipulate their earnings upward before listing to meet HOSE listing requirements and appear more promising to prospective investors, current shareholders. More details on the earnings management around the specific events will be discussed in the next section.

\section{Earnings Management Literature and Hypothesis Development}

Earnings management is an intriguing topic for researchers. The growing body of research increases attention on earnings management of firms around the time of events (IPOs, SEOs, and new listings). The asymmetric information theory and agency theory have been the main explanation for earnings management. In the case of equity offerings, an agency relationship exists when the two parties, which are the principal (shareholders) and the agent (managers), have different interests. The conflict emerges when managers want to maximise their benefits which are not in the best interest of shareholders. Due to high information asymmetry during equity issues events, managers have more superior knowledge and more information about the internal operation of a firm than the investors, enabling the managers to act in their own best interests rather than in shareholders' best interests. According to agency theory, managers (issuers) have strong incentives and opportunities to issue stocks at high prices or to increase listing opportunities by manipulating earnings through accounting practices to give investors highly optimistic expectations about future earnings (Eiman, 2013; Qintao, 2007).

An IPO is one of the most common events that induce manager to inflate their earnings through income-increasing accruals. Studies have empirically examined the existence of earnings management around IPO year (including pre-IPO and IPO year). However, the earnings management around this phenomenon provides conflicting results in the literature. One view provides strong empirical evidence that some firms manipulate accruals aggressively or earnings upward around new issuance (Ahmad-Zaluki, 2008; Chiraz, 2013; DuCharme et al., 2004; Gresse \& Gajewski, 2006; Li et al., 2005; Mangala \& Dhanda, 2019; Nuryaman, 2013; Roosenboom et al., 2003; Teoh et al., 1998a, 1998b). Different views are provided 
by researchers such as Beaver et al. (2000), Qintao (2007), Ball and Shivakumar (2008), Armstrong et al. (2008), Premti (2013), and Chou et al. (2009) which show no evidence of earnings signals around new issuance.

In SEO, firms seek new investors to increase capital through new equity issuance. Therefore, before SEO, it is likely that firms inflate their earnings. Rangan (1998) found positive accruals during the year around SEO. Kinnunen et al. (2000), Shivakumar (2000), Zhou and Elder (2004), DuCharme et al. (2004), Pastor and Poveda (2005), and Cohen and Zarowin (2008) have similar interpretations as the one offered by Rangan (1998).

Listing is the most common way for firms to raise capital while strengthening their reflectivity and reputation. Any firm to be listed on the stock exchange must conform to a set of conditions and rules issued by the governing bodies such as profit requirement (mandates that firms must achieve a minimum profit over several years prior to listing). Therefore, in order to be listed on the stock exchange, firms might inflate their earnings. Using the sample of 68 firms listed on Kuwait stock exchange from 1997 to 2007, Eiman (2013) found that issuers have incentives to inflate earnings in the pre-listing year to meet the profit targets. In contrast, in the case of listing requirement reforms in Malaysia to enhance the financial reporting transparency, Sahlan (2011) studied the effect of listing requirement reform on the incidence of earnings management. The study provides evidence to support that the reforms had the intended impact on reducing the incidence of earnings management. Charitou and Louca (2003) used the data of 165 Canadian companies during the period from 1983 to 2001 to find that companies tend to inflate earnings by taking positive accruals before listing on the US stock exchange. Similarly, Lin (2003) studied 584 firms that switch from Nasdaq Stock Market (Nasdaq) to New York Stock Exchange (NYSE) and American Express Company (Amex), and from Amex to NYSE, found that managers manipulated earnings in the year prior to switching. The evidence is consistent with Lang et al. (2006) and Ndubizu (2007). A different view is provided by Jia and Zhou (2019). The study used the sample of firms listing in both mainland Chinese stock exchange and Hong Kong stock exchange (crosslisting). The authors found that cross-listing has reduced earnings management. It means that firms listed on both stock exchanges have a lower level of earnings management than those listed on mainland Chinese stock exchange.

In a nutshell, a review of the earnings management literature reveals that while earnings management during issuance of equity is well documented, little is known about the link between new listings and earnings management. The asymmetric information theory and the agency theory indicate that insiders have strong 
incentives to inflate their earnings prior to listing to meet the listing requirement and to have the best possible stocks price. Furthermore, for Vietnam until now, there is no study to test earnings management incentives around listing events. Thus, it is necessary to empirically investigate this phenomenon in the Vietnam market for reasons such as low transparency, weak legal environment, and lack of regulatory coordination (Zingales, 2009). In addition to contributing to the Vietnam stock market literature, the study has documented the change of the listing conditions imposed by the government. The following hypotheses are given:

H1: Firms listed on HOSE present positive earnings management in the year before listing event.

H2: Firms listed on HOSE present higher earnings management in the preceding year than in post-listing years.

As mentioned above, a major listing requirement in effect since 15 September 2012 has introduced tougher listing conditions which requires all eligible firms to be listed on the Vietnamese securities market to have a minimum ROE ratio in pre-listing year to be $5 \%$. Because of this substantial change, firms listed on HOSE after 15 September 2012 are expected to have stronger incentives to manipulate their earnings upward than firms listed before 15 September 2012. Thus, the following hypothesis is formulated:

H3: Firms listed following the change in profit requirement present greater earnings management in the preceding year.

\section{METHODOLOGY}

\section{Measures of Earnings Management}

In the earnings management literature, earnings are known to be managed through the following: (1) real operating decisions: real earnings management such as asset sales and change in $\mathrm{R} \& \mathrm{D}$ expenditure, affecting selling and administrative expenses (Roychowdhury, 2006; Zang, 2012); (2) accruals management through changes in estimates and accounting policies; and (3) classification-shifting (McVay, 2006). Scholars argue that these manipulations are not cost free and the cost differs among these methods. According to researchers, while accruals management method and classification shifting method bear a relatively low cost (McVay, 2006), manipulation by real activities bears the highest cost (Ronen \& Yaari, 2008). In addition, there is no existing perfect method in detecting potential 
earnings management. Studies in this field have shown that the aggregate accruals method is the most common method to test for earnings management. Therefore, this research emphasised on the aggregate accruals method.

Accruals are broken down into discretionary and non-discretionary (Healy, 1985) which is not directly measurable. While non-discretionary accruals are driven by prevailing business conditions, discretionary accruals (DA) are managerdetermined in which managers have control of practicing discretion over accounting methods and estimates. Therefore, discretionary accruals are used to a great extent in earnings management. Separating accruals into discretionary and non-discretionary is difficult. Therefore, non-discretionary components are evaluated first from regression models, then the discretionary accruals parts are the residuals of the regression. Since earnings management is difficult to identify, the literature makes various attempts to develop a wide range of accrual models to detect earnings management. In general, researchers have applied the most popular models in literature review to determine the power of each model and then identify the most appropriate way to detect earnings management. Each model has different explanatory power in different countries. However, there is no consensus on how efficient the models are in detecting earnings management (Susana et al., 2017). Because each model has its own advantages in detecting only one aspect of earnings management, there will be no perfect model for detecting earnings management.

To be consistent with previous studies in literature review, this research employs the modified Jones model for computing earnings management, which is known as the most powerful model in detecting earnings management. In addition, Ball and Shivakumar (2008) and Armstrong et al. (2008) argue that "using low values of lagged total assets $(t-1)$ in model produce extreme values of discretionary accruals estimates since pre-listing total assets are relatively small and not representative of the listing-year or post-listing year total assets." This research estimates the first DA model:

Model 1: The modified Jones model - Total accruals model

$$
\begin{aligned}
& \frac{T A_{i t}}{A_{i}, \frac{t-1+t}{2}}=\alpha_{0}+\alpha_{1} * \frac{1}{A_{i}, \frac{t-1+t}{2}}+\alpha_{2} * \frac{\Delta R E V_{i t}}{A_{i}, \frac{t-1+t}{2}}+\alpha_{3} * \frac{P P E_{i t}}{A_{i}, \frac{t-1+t}{2}} \\
& N D A_{i t}=\alpha_{0}+\alpha_{1} * \frac{1}{A_{i}, \frac{t-1+t}{2}}+\alpha_{2} * \frac{\Delta R E V_{i t}-\Delta T R_{i t}}{A_{i}, \frac{t-1+t}{2}}+\alpha_{3} * \frac{P P E_{i t}}{A_{i}, \frac{t-1+t}{2}}
\end{aligned}
$$


(1.3) $D A_{i t}=\frac{T A_{i t}}{A_{i}, \frac{t-1+t}{2}}-N D A_{i t}$

$$
\frac{T A_{i t}}{A_{i}, \frac{t-1+t}{2}}=\frac{\left(N I B E_{i t}-C F O_{i t}\right)}{A_{i}, \frac{t-1+t}{2}}
$$

Where,

$T A_{i t}$ : Total accruals for company $i$ in year $t$

$D A_{i t}$ : Discretionary accruals for company $i$ in year $t$

$N D A_{i t}$ : Non-discretionary accruals for company $i$ in year $t$

$N I B E_{i t}$ : Company $i$ 's net income in year $t$

$C F O_{i t}$ : Company $i$ 's net cash flow in year $t$

$A_{i}, \frac{t-1+t}{2}$ : Average of beginning and end of year total asset for company $i$

$\triangle R E V_{i t}$ : The change in revenues for company $i$ in year $t$

$\triangle R E C_{i t}$ : The change in net receivables for company $i$ in year $t$

$P P E_{i t}$ : Gross property plant and equipment at the end of year $t$

$\alpha_{1}, \alpha_{2}, \alpha_{3}$ : industry-specific parameters

Another group of scholars such as Kang and Sivaramakrishnan (1995), Teoh et al. (1998a, 1998b), DuCharme et al. (2001), Roosenboom et al. (2003), and AhmadZaluki et al. (2011) claim that Jones model limits control of working capital accruals activity in which managers might have less discretion over long-term accruals than over short-term. Thus, they modified the traditional Jones model by using the current accruals in their research as another alternative to predict earnings management. A current accruals model can be obtained as below:

\section{Model 2: The second version of modified Jones model - Current accruals model}

$$
\frac{C A_{i t}}{A_{i}, \frac{t-1+t}{2}}=\alpha_{0}+\alpha_{1} * \frac{1}{A_{i}, \frac{t-1+t}{2}}+\alpha_{2} * \frac{\Delta R E V_{i t}}{A_{i}, \frac{t-1+t}{2}}+\varepsilon_{i t}
$$

$$
N D C A_{i t}=\alpha_{0}+\alpha_{1} * \frac{1}{A_{i}, \frac{t-1+t}{2}}+\alpha_{2} * \frac{\Delta R E V_{i t}-\Delta T R_{i t}}{A_{i}, \frac{t-1+t}{2}}
$$

$$
D C A_{i t}=\frac{C A_{i t}}{A_{i}, \frac{t-1+t}{2}}-N D C A_{i t}
$$

$$
C A_{i t}=\Delta \text { CAssets }_{i t}-\Delta \operatorname{Cash}_{i t}-\Delta C L_{i t}+\Delta S T D_{i t}
$$


Where,

$C A_{i t}$ : Current accruals for company $i$ in year $t$

$\Delta$ CAssets $_{i t}$ : The change in current assets for company $i$ in year $t$

$\Delta$ Cash $_{i t}$ : The change in cash and cash equivalent for company $i$ in year $t$

$\triangle C L_{i t}$ : The change in current liabilities for company $i$ in year $t$

$\triangle S T D_{i t}$ : The change in debt included in current liabilities for company $i$ in year $t$

$N D C A_{i t}$ : Nondiscretionary current accruals for company $i$ in year $t$

$D C A_{i t}$ : Discretionary current accruals for company $i$ in year $t$

\section{Model 3: The cash flow model}

The third model is suggested by Dechow (1994) and Francis et al. (2005). They argue that accruals quality depends on forecasting business's cash flow because accruals accounting separates the timing of cash flows from the timing of their recognition in financial statement.

$$
\begin{aligned}
\frac{T A_{i t}}{A_{i}, \frac{t-1+t}{2}}= & \alpha_{0}+\alpha_{1} * \frac{1}{A_{i}, \frac{t-1+t}{2}}+\alpha_{2} * \frac{\Delta R E V_{i t}}{A_{i}, \frac{t-1+t}{2}}+\alpha_{3} * \frac{P P E_{i t}}{A_{i}, \frac{t-1+t}{2}} \\
& +\alpha_{4} * \frac{\Delta C F O_{i t}}{A_{i}, \frac{t-1+t}{2}}+\varepsilon_{i t} \\
\frac{C A_{i t}}{A_{i}, \frac{t-1+t}{2}}= & \alpha_{0}+\alpha_{1} * \frac{1}{A_{i}, \frac{t-1+t}{2}}+\alpha_{2} * \frac{\Delta R E V_{i t}}{A_{i}, \frac{t-1+t}{2}}+\alpha_{4} * \frac{\Delta C F O_{i t}}{A_{i}, \frac{t-1+t}{2}}+\varepsilon_{i t}
\end{aligned}
$$

Where,

$C F O_{i t}$ : the change in cash flow of firm $i$ in year $t$

\section{Sample Selection and Data}

By adopting Global Industry Classification Standards, HOSE consists of 11 industrial sectors. In this research, financial companies are not included in the sample because of their different reporting practices. In addition, the research has eliminated communication service companies and information technology companies because the datasets from these sectors are not sufficient to estimate accruals. Therefore, our initial sample includes 334 firms listed in 8 sectors including real estate, consumer staples, industrials, utilities, materials, consumer discretionary, energy, and healthcare. In order to estimate discretionary accruals in the year prior to listing, financial statements for the previous two years are acquired, taking into consideration that data before 2009 might not be available. 
Besides, the sample data ends in 2017 to allow sufficient time to collect available annual reports of newly listed firms. Therefore, the final sample consists of 189 firms listed on HOSE from 2009 to 2017, in which 17 firms are in consumer staples, 24 firms in consumer discretionary, 34 firms in materials, 61 firms in industrials, 12 firms in utilities, 33 firms in real estate, 5 firms in healthcare, and 3 firms in energy sector.

\section{RESULTS AND ANALYSIS}

\section{Testing the Presence of Earnings Management Around Listing Event}

The study provides descriptive statistics of the sample firms' discretionary accruals [DA; DA(CFO)] and discretionary current accruals [DCA; DCA(CFO)] surrounding listing events based on four models in preceding year (year -1 ), listing year (year 0 ), and two years after listing (year +1 and year +2 ). As shown in Table 2, all models show the means and medians of DA, DA(CFO), DCA, and DCA(CFO) are positive in preceding year (year -1$)$. Interestingly, almost models show the same result of lower DA and DCA in (year 0$)$, (year +1$)$, and (year +2 ) than in (year -1). This study uses both two-tailed $t$-tests and Wilcoxon signedrank test to determine whether the means and medians of DA and DCA in the preceding year, listing year, and subsequent years are statistically different from zero.

To specify, Panels B and D show the highest positive figure of means and medians of DCA [DCA(CFO)] in pre-listing year. In (year -1 ), both tests show that the means and medians of DCA [DCA(CFO)] are statistically significant different from zero at $1 \%$ level. The opposite was true in listing year and two consecutive years immediately after listing as the means and medians are not statistically significant at conventional levels except for the median of cash flow model in listing year.

By comparison, Panels $\mathrm{A}$ and $\mathrm{C}$ report the highest level of positive means of DA $[\mathrm{DA}(\mathrm{CFO})]$ in pre-listing year. Its mean are 0.0146 for modified Jones model and 0.0171 for cash flow model. However, only the median of cash flow model in pre-listing year and median of modified Jones model in year +1 are statistically significant. The rest is not significant in both pre-listing year, listing year, and subsequent years. The test means and medians of DA derived from the cash flow model and modified Jones model based on total accruals are inconsistent. While the former shows a positive insignificance in existence of earnings management in all models, the latter shows a positive significance DA 
in $($ year +1$)$ and $\mathrm{DA}(\mathrm{CFO})$ in (year -1$)$. Therefore, there is limited evidence to conclude that firms listed on HOSE present positive earnings management in the year before listing event, when models based on total accruals are adopted.

Table 2 shows the results used to test the first hypothesis, H1. H1 is supported as firms listed on HOSE exhibit a high magnitude of positive earnings management in pre-listing year when using current accruals models. However, models based on total accruals provide mixed results. Hence, greater reliance depends on the results of the current accruals models, which support $\mathrm{H} 1$.

Table 2

Descriptive statistics for the $D A$ and $D C A$

\begin{tabular}{lccllc}
\hline \multicolumn{1}{c}{ Mean } & \multicolumn{1}{c}{ Median } & \multicolumn{1}{c}{ Min } & \multicolumn{1}{c}{ Max } & SD \\
\hline Panel A: Modified Jones model & & & & & \\
DA year -1 & 0.0146 & 0.0233 & $(0.9179)$ & 1.1010 & 0.2443 \\
DA year 0 & $(0.0166)$ & $(0.0025)$ & $(1.3507)$ & 0.9412 & 0.2389 \\
DA year +1 & 0.0024 & $0.0234^{* *}$ & $(1.54)$ & 1.17 & 0.2445 \\
DA year +2 & $(0.0053)$ & $(0.0020)$ & $(0.81)$ & 0.32 & 0.1331 \\
Panel B: Currents accruals model & & & & \\
DCA year -1 & $0.0726^{* * *}$ & $0.0452^{* * *}$ & $(0.5189)$ & 1.0788 & 0.2349 \\
DCA year 0 & 0.0146 & 0.0049 & $(0.5196)$ & 0.8820 & 0.1936 \\
DCA year +1 & 0.0106 & 0.020 & $(1.29)$ & 0.80 & 0.2314 \\
DCA year +2 & $(0.0067)$ & 0.0011 & $(0.56)$ & 0.36 & 0.1437 \\
Panel C: Cash flow model based on total accruals & & & & \\
DA(CF0) year -1 & 0.0171 & $0.0303^{* * *}$ & $(0.9744)$ & 0.5075 & 0.1884 \\
DA(CF0) year 0 & 0.0002 & 0.0223 & $(1.3498)$ & 0.4915 & 0.1911 \\
DA(CFO) year +1 & $(0.0029)$ & 0.0129 & $(1.95)$ & 1.30 & 0.2591 \\
DA(CFO) year +2 & 0.0043 & 0.0028 & $(0.78)$ & 1.32 & 0.1680 \\
Panel D: Cash flow model based on current accruals & & & \\
DCA(CF0) year -1 & $0.0815^{* * *}$ & $0.0631^{* * *}$ & $(0.9532)$ & 1.0987 & 0.2409 \\
DCA(CF0) year 0 & 0.0245 & $0.0169^{* *}$ & $(0.9363)$ & 0.6103 & 0.2063 \\
DCA(CF0) year +1 & 0.0113 & 0.006 & $(1.54)$ & 1.14 & 0.2437 \\
DCA(CF0) year +2 & 0.0045 & 0.011 & $(0.69)$ & 1.43 & 0.1887 \\
\hline
\end{tabular}

Notes: ${ }^{* * *},{ }^{* *}$, and ${ }^{*}$ represent significance levels at $1 \%, 5 \%$, and $10 \%$

Year -1 is considered as a year-end before the listing date. Year 0 refers as fiscal year ending after listing.

Year +1 and Year +2 refer to the first and second post-listing financial statements issued after listing. 
In summary, the research provides some empirical evidence for existence of earning management before listing on HOSE. Firms listed on HOSE show significantly greater positive earnings management in current accrual models than in total accrual ones. The first interpretation is that in order to be listed on HOSE, firms use current discretionary accruals to inflate their earnings in prelisting year to meet profit requirements. Moreover, managers prefer to use discretion over current accruals, because it is known as "the component most easily subjected to successful managerial manipulation" (Teoh et al., 1998b, p. 64). In addition, current accruals are likely to be more flexible and important than non-current accruals in improving earnings since current accruals have higher degree of judgment with regard to its estimation (Dechow, 1994). Noncurrent accruals such as depreciation and change in deferred taxes are more visible than current accruals and need more time to change before listing. Therefore, consistent with previous studies, managers of HOSE firms favour adjusting current accruals in an attempt to improve earnings in the year before listing, which cannot be sustained in post-listing years.

\section{Testing the Earnings Management in the Pre-Listing Year and Post-Listing Years}

The result above indicates that earnings management in year -1 is greater than year 0 and two consecutive years after listing. In order to investigate the significance of the differences, the research uses t-statistics from t-tests and Wilcoxon tests to determine if earnings management in year -1 is statistically higher than in year 0 and subsequent years in which the former tests the differences in means of earnings management and the latter tests the differences in medians of earnings management. The result of matched-paired t-test in Table 3 shows that the means of DCA [DCA(CFO)] are statistically significantly higher in year -1 than in year 0 and subsequent years at $5 \%$ and $1 \%$ level, respectively. In contrast, the means of DA (measured by two total accruals models) are lower in year 0 and two subsequent years after listing than in year -1 , but the difference is not significant for both models. Hence, listing firms in HOSE exhibit significantly higher positive discretionary current accruals in year -1 than in year 0 and two consecutive years immediately after listing for two current accruals models, which support H2. Current accruals model can detect a significant and positive level of earnings management in the year preceding the listing. 
Table 3

Comparison between year -1 and year 0 , year +1 , year +2 in earnings management based on matched pairs t-test

\begin{tabular}{llcc}
\hline Model test & Testing period & t-value & $p$-value \\
\hline A. Models based on total accruals & & & \\
1. Modified Jones model (DA) & Year -1 and Year 0 & 1.2940 & 0.1973 \\
& Year -1 and Year +1 & 0.5312 & 0.5959 \\
& Year -1 and Year +2 & 0.9876 & 0.3246 \\
& Year -1 and Year 0 & 1.069 & 0.2864 \\
2. Cashflow [DA(CFO)] & Year -1 and Year +1 & 0.8945 & 0.3722 \\
& Year -1 and Year +2 & 0.7666 & 0.4443 \\
B. Model based on current accruals & & & \\
1. Current accruals (DCA) & Year -1 and Year 0 & 2.4429 & 0.0155 \\
& Year -1 and Year +1 & 2.5401 & 0.0119 \\
& Year -1 and Year +2 & 3.7986 & 0.0002 \\
2. Cashflow [DCA(CFO)] & Year -1 and Year 0 & 2.4254 & 0.0162 \\
& Year -1 and Year +1 & 2.5552 & 0.0114 \\
& Year -1 and Year +2 & 3.4243 & 0.0008 \\
\hline
\end{tabular}

In Table 4, positive signed ranks mean that the medians of DA [DA(CFO)] and DCA $[\mathrm{DCA}(\mathrm{CFO})]$ variables are greater in year -1 than those in year 0 , year +1 , and year +2 . The opposite is true in negative ranks. In general, there are fewer negative ranks than positive ranks in all models. It can be observed from Panel B that the significant differences between the medians are at conventional levels in both current accruals models with greater positive DCA in the year -1 than that in the year 0 and two subsequent years after listing. By comparison, models based on total accruals show that median DA in year -1 are significantly greater than median in year 0 for the Jones model at $10 \%$ level, as shown in Panel A. However, the reduction in the median DA from the year -1 to the year +1 and year +2 is not significant. Contrary to results found in modified Jones model, DA(CFO) from the cashflow model indicates a statistically significant difference among year -1 and two consecutive years immediately after listing at $10 \%$ level, but the difference is not significant between year -1 and year 0 .

On the other hand, medians of DA derived from models based on total accruals show a significant difference in some years as compared to the pre-listing year, but the opposite result is found from the means of discretionary accruals. Hence, there was insufficient evidence to prove that earnings management (measured by total 
accruals) are significantly higher in the pre-listing year as compared to that in the listing year and two consecutive years immediately after listing.

Table 4

Comparison between year -1 and year 0 , year +1 , year +2 in earnings management based on Wilcoxon signed-rank test

\begin{tabular}{|c|c|c|c|c|c|}
\hline Model test & Testing period & $\begin{array}{c}\text { Positive } \\
\text { rank }\end{array}$ & $\begin{array}{l}\text { Negative } \\
\text { rank }\end{array}$ & $p$-value & $z$-score \\
\hline \multicolumn{6}{|c|}{ A. Model based on total accruals } \\
\hline \multirow{3}{*}{$\begin{array}{l}\text { 1. Modified Jones } \\
\text { model (DA) }\end{array}$} & Year -1 and Year 0 & 108 & 81 & 0.0585 & 1.8920 \\
\hline & Year -1 and Year +1 & 94 & 95 & 0.6208 & 0.495 \\
\hline & Year -1 and Year +2 & 107 & 82 & 0.1071 & 1.6110 \\
\hline \multirow{3}{*}{$\begin{array}{l}\text { 2. Cashflow DA } \\
(\mathrm{CFO})\end{array}$} & Year -1 and Year 0 & 105 & 84 & 0.1929 & 1.3020 \\
\hline & Year -1 and Year +1 & 107 & 82 & 0.0618 & 1.868 \\
\hline & Year -1 and Year +2 & 103 & 86 & 0.0987 & 1.651 \\
\hline \multicolumn{6}{|c|}{ B. Model based on current accruals } \\
\hline \multirow{3}{*}{$\begin{array}{l}\text { 1. Current accruals } \\
\text { (DCA) }\end{array}$} & Year -1 and Year 0 & 106 & 83 & 0.0329 & 2.1330 \\
\hline & Year -1 and Year +1 & 101 & 88 & 0.098 & 1.658 \\
\hline & Year -1 and Year +2 & 107 & 82 & 0.0052 & 2.797 \\
\hline \multirow{3}{*}{$\begin{array}{l}\text { 2. Cashflow DCA } \\
(\mathrm{CFO})\end{array}$} & Year -1 and Year 0 & 105 & 84 & 0.0206 & 2.3150 \\
\hline & Year -1 and Year +1 & 106 & 83 & 0.0232 & 2.27 \\
\hline & Year -1 and Year +2 & 107 & 82 & 0.0014 & 3.193 \\
\hline
\end{tabular}

In summary, the results from $t$-test reported in Table 3 are consistent with the results from Wilcoxon signed-rank test presented in Table 4 for all current accruals models. When models based on current accruals are considered, the findings suggest that HOSE-listed firms show significantly greater positive earnings management in the year before listing than in post-listing years, including two consecutive years immediately after listing, which validates H2. However, the evidence related to $\mathrm{H} 2$ is mixed when using models based on total accruals.

Overall, consistent with previous studies and agency theory, the results obtained from testing $\mathrm{H} 1$ and $\mathrm{H} 2$ suggest that in an attempt to meet the pre-listing profit requirement, the firms listed on HOSE may have incentives to inflate their earnings in the listing year through the current accruals. However, the high level of current accruals cannot be sustained in post-listing years.

As discussed in previous sections, there was no pre-listing profit requirement (ROE) before 15 September 2012. Then, a new requirement for ROE in the latest 
year to be at least $5 \%$ has been added in the new decree. $\mathrm{H} 3$ states that firms listed on HOSE after 15 September 2012 might have stronger incentives to manipulate their earnings upward in year -1 than firms listed before 15 September 2012.

\section{Testing the Pre-Listing Earnings Management and the Change in Profit Requirement}

The sample of 189 firms is separated into two groups. Group 1 consists of 115 firms listed before the new profit requirement (before 15 September 2012), the rest of 74 firms listed after the new profit requirement (after 15 September 2012) is in Group 2.

Three tests are undertaken to test H3. First, two-sample $t$-test is performed to investigate whether the differences in the means of discretionary accruals and discretionary current accruals of two groups are significant. Second, the statistical significance of the difference in medians of the two groups is tested with median test. In addition, in order to investigate whether Group 2 presents more significantly the level of discretionary accruals and the level of discretionary current accruals in the year preceding the listing than Group 1, the Mann-Whitney U-test is undertaken. Table 5 indicates that the means of accruals based on all models are greater in Group 2 than those in Group 1. However, the differences are not significant. Similarly, there is no statistically significant difference between two groups. Therefore, the test results do not support $\mathrm{H} 3$, which implies that the change in profit requirement (ROE at least $5 \%$ ) is not related to a significant increase in earnings management.

Table 5

Comparisons of earnings management between Group 1 and Group 2 in year $t^{-1}$

\begin{tabular}{|c|c|c|c|c|c|c|c|}
\hline \multirow{2}{*}{ Model test } & \multicolumn{3}{|c|}{ Two-sample t-test } & \multicolumn{3}{|c|}{ Median test } & \multirow{2}{*}{$\begin{array}{c}\text { Mann- } \\
\text { Whitney } \\
\text { U-test } \\
\\
p \text {-value }\end{array}$} \\
\hline & $\begin{array}{c}\text { Group } 1 \\
\text { DA(DCA) } \\
\text { mean }\end{array}$ & $\begin{array}{c}\text { Group } 2 \\
\text { DA(DCA) } \\
\text { mean }\end{array}$ & $p$-value & $\begin{array}{c}\text { Group } 1 \\
\text { DA(DCA) } \\
\text { median }\end{array}$ & $\begin{array}{c}\text { Group } 2 \\
\text { DA(DCA) } \\
\text { median }\end{array}$ & $p$-value & \\
\hline \multicolumn{8}{|c|}{ Models based on total accruals } \\
\hline $\begin{array}{l}\text { 1. Modified Jones } \\
\text { model }\end{array}$ & 0.0117 & 0.0190 & 0.8420 & 0.0315 & 0.0130 & 0.325 & 0.8659 \\
\hline 2. Cashflow & 0.0089 & 0.0297 & 0.4597 & 0.0319 & 0.0211 & 0.697 & 0.8232 \\
\hline \multicolumn{8}{|c|}{ Models based on current accruals } \\
\hline 1. Current accruals & 0.0682 & 0.0795 & 0.7468 & 0.0482 & 0.0449 & 0.928 & 0.5132 \\
\hline 2. Cashflow & 0.0785 & 0.0862 & 0.8302 & 0.0650 & 0.0570 & 0.928 & 0.6085 \\
\hline
\end{tabular}


In an effort to enhance the quality of listed firms, regulators have imposed stricter listing requirement by increasing capital requirement and introduced new profit requirement (ROE) after 15 September 2012. As opposed to tighter regulations, the institutional setting of the Vietnam market provides evidence that both groups have the same incentives to manipulate their earnings upward in pre-listing year to its maximum level. Newly listed companies use current accruals to inflate earnings of pre-listing year in order to be eligible for listing on the HOSE without the impact of new regulations.

\section{CONCLUSION}

Literature review presents several motivations for earnings management practices around the event of share issuance and new listings. Attention is given to issuers on HOSE due to their inflation of earnings around new listing events. The empirical approach uses discretionary accruals to measure earnings management. Four cross-sectional models, including two total accruals models and two current accruals models, are necessary for computing the discretionary accruals proxies. The initial results provide empirical evidence for three hypotheses that firms tend to increase their earnings before listing. Based on estimates from four models using both total accruals and current accruals, parametric and nonparametric tests are used to examine the validity of three hypotheses. The research provides evidence to support the existence of earnings management in pre-listing year with significantly greater positive earnings management in current accrual models. However, when using models based on total accruals, there is insufficient evidence for the existence of the earnings management before listing. Besides, the empirical findings suggest that the accruals means and accruals medians are significantly higher in pre-listing year than those in post-listing years only when two models of current accruals are considered.

Overall, given the conflicting results in previous studies, the study provides further evidence for ongoing debate on the existence of earnings management phenomenon. The findings are in line with literature review which suggest that HOSE-listed firms can use current discretionary accruals to deliberately manipulate earnings in an attempt to meet profit requirements for listing. These firms then show a falling trend of earnings management in post-listing years. The findings agree with the views expressed by Teoh et al. (1998a, 1998b), Dechow and Dichev (2002), and Eiman (2013) in explaining the use of current discretionary accruals. According to Teoh et al. (1998b), current accruals are most easily subjected to manipulation by managers. In addition, current accruals are likely to be more flexible and important than long-term accruals in improving 
earnings. Current accruals which occur frequently have higher degree of subjective judgment with regard to its estimation (Dechow \& Dichev, 2002; Teoh et al., 1998b).

Since 15 September 2012, HOSE has imposed new profit requirements for all new listings. By dividing sample firms into two groups, in which Group 1 consisting of firms listed before 15 September 2012 and Group 2 consisting of firms listed after that time, the results indicate that Group 1 and Group 2 are inflating their profits in pre-listing year similarly. The difference between the earnings management of two groups is not significant in pre-listing year. In other words, the institutional setting of HOSE also demonstrates that two groups have the same incentives to manipulate their earnings upward in listing year to meet the prelisting profit requirement.

Finally, the study suggests that managers of newly listed firms in Vietnam attempt to boost their earnings in the year preceding the listing by taking advantage of current accruals. However, positive level of earnings management is not sustained in post-listing years. Evidence from this study can help managers, auditors, market's policy, and investors better understand the quality of financial reporting of newly listed firms.

Despite the overall contribution, there are limitations in this study. First, this study is limited to the sample of listed firms in HOSE. Second, this study could only be generalised to similar market. In addition, the small sample is subjected to bias which stems from size limitation. Third, due to the lack of data in the years before listing, the period of research was limited to only one year prior to the listing. This may be an inadequate length of time for data analysis. Finally, there are some problems related to the technique of measuring earnings management. According to Fields et al. (2001), using only accrual-based earnings management method may not capture the entire level of earnings management behaviour. In order to address the limitation, a more comprehensive approach to investigating earnings management around listing by using varied earnings management techniques, such as real earnings management, would be a potential topic for future research.

\section{ACKNOWLEDGEMENTS}

This research is funded by the National Economics University, Hanoi, Vietnam. 


\section{REFERENCES}

Aharony, J., Lin, C., \& Loeb, M. (1993). Initial public offerings, accounting choices, and earnings management. Contemporary Accounting Research, 10(1), 61-81. https://doi.org/10.1111/j.1911-3846.1993.tb00382.x

Ahmad-Zaluki, N. A. (2008). Post-IPO operating performance and earnings management. International Business Research, 1(2), 39-48. https://doi.org/10.5539/ibr .$v \ln 2 \mathrm{p} 39$

Ahmad-Zaluki, N., Campbell, K., \& Goodacre, A. (2011). Earnings management in Malaysian IPOs: The East Asian crisis, ownership control, and post-IPO performance. The International Journal of Accounting, 46(2), 111-137. https://doi.org/10.1016/j.intacc.2011.04.001

Armstrong, C., Foster, G., \& Taylor, D. (2008). Earnings management around initial public offerings: A re-examination. SSRN Electronic Journal. https://doi.org/10.2139/ ssrn. 1147328

Ball, R., \& Shivakumar, L. (2008). Earnings quality at initial public offerings. Journal of Accounting and Economics, 45(2-3), 324-349. https://doi.org/10.1016/j .jacceco.2007.12.001

Beaver, W., McNichols, M., \& Nelson, K. (2000). Do firms issuing equity manage their earnings? Evidence from the property-casualty insurance industry. SSRN Electronic Journal. https://doi.org/10.2139/ssrn.203408

Charitou, A., \& Louca, C. (2003). Earnings management by foreign firms preceding their listing in US stock exchanges. SSRN Electronic Journal. https://doi.org/10 $.2139 / \mathrm{ssrn} .392024$

Chiraz, D. (2013). Earnings management and performance of French IPO companies. Journal of Accounting and Taxation, 5(1), 1-14. https://doi.org/10.5897/ JAT2013.0106

Chou, D. -W., Gombola, M., \& Liu, F. -Y. (2009). Earnings management and long-run stock performance following private equity placements. Review of Quantitative Finance and Accounting, 34(2), 225-245. https://doi.org/10.1007/s11156-009 $-0129-8$

Cohen, D., \& Zarowin, P. (2008). Accrual-based and real earnings management activities around seasoned equity offerings. SSRN Electronic Journal. https://doi.org/ $10.2139 /$ ssrn. 1081939

Dechow, P. M. (1994). Accounting earnings and cash flows as measures of firm performance: The role of accounting accruals. Journal of Accounting \& Economics, 18(1), 3-42. https://doi.org/10.1016/0165-4101(94)90016-7

Dechow, P., \& Dichev, I. (2002). The quality of accruals and earnings: The role of accrual estimation errors. The Accounting Review, 77(s-1), 35-59. https://doi.org/10.2308/accr.2002.77.s-1.35

Dechow, P. M., Sloan, R. G., \& Sweeney, A. P. (1995). Detecting earnings management. The Accounting Review, 70(2), 193-225. 
DuCharme, L., Malatesta, P., \& Sefcik, S. (2001). Earnings management: IPO valuation and subsequent performance. Journal of Accounting, Auditing and Finance, 16(4), 369-396. https://doi.org/10.1177/0148558X0101600409

DuCharme, L., Malatesta, P., \& Sefcik, S. (2004). Earnings management, stock issues, and shareholder lawsuits. Journal of Financial Economics, 71(1), 27-49. https://doi.org/10.1016/S0304-405X(03)00182-X

Eiman, A. (2013). Earnings management practices. PhD dissertation, University of Southern Queensland.

Fields, T., Lyz, T., \& Vincent, L. (2001). Empirical research on accounting choice. Journal of Accounting and Economics, 31(1-3), 255-308. https://doi.org/10 .1016/S0165-4101(01)00028-3

Francis, J., LaFond, R., Olsson, P., \& Schipper, K. (2005). The market pricing of accruals quality. Journal of Accounting and Economics, 39(2), 295-327. https://doi.org/10.1016/j.jacceco.2004.06.003

Friedlan, J. (1994). Accounting choices of issuers of initial public offerings. Contemporary Accounting Research, 11(1), 1-31. https://doi.org/10.1111/j.1911-3846.1994 .tb00434.x

Goncharov, I., \& Zimmermann, J. (2007). Do accounting standards influence the level of earnings management? Evidence from Germany. Swiss Journal of Business Research and Practice, 61(5), 371-388.

Government Decree No. 14 Detailing the Implementation of a Number of Articles of the Law on Securities. (2007). Retrieved 17 April 2020 from http://www.ssc .gov.vn/ubck/faces/oracle/webcenter/portalapp/pages/en/legaldocumentdetail .jspx?dDocName $=$ APPSSCGOVVN162127563\&_afrLoop $=17861017506000 \&$ afrWindowMode $=0 \&$ afrWindowId $=$ null $\# \% 40 \% 3 \mathrm{~F}$ afrWindowId $\% 3$ Dnull \%26_afrLoop\%3D17861017506000\%26dDocName\%3DAPPSSCGOVVN 162127563\%26_afrWindowMode\%3D0\%26_adf.ctrlstate\%3D16kwfc5g8k_21

Government Decree No. 58 Stipulating in Detail and Guiding the Implementation of a Number of Articles of the Securities Law and the Law Amending and Supplementing a Number of Articles of Securities Law. (2012). Retrieved 17 April 2020 from http://www.ssc.gov.vn/ubck/contentattachfile/idcplg?dID $=91011 \& \mathrm{dDocName}=$ APPSSCGOVVN162091208\&Rendition $=$ Decree $\% 20$ No.\%2058/2012/ND-CP\&filename=Decree.58.2012.ND-CP.pdf

Gresse, C., \& Gajewski, J. (2006). A survey of the European IPO market. Bruxelles: Centre for European Policy Studies. Retrieved 14 August 2019 from https://basepub. dauphine.fr/handle/123456789/8670

Healy, P. M. (1985). The effect of bonus schemes on accounting decisions. Journal of Accounting and Economics, 7(1-3), 85-107. https://doi.org/10.1016/0165 $-4101(85) 90029-1$

Healy, P., \& Wahlen, J. (1999). A review of the earnings management literature and its implications for standard setting. SSRN Electronic Journal. https://doi.org/ $10.2139 /$ ssrn. 156445 
Jia, Q., \& Zhou, J. (2019). The impact of cross-listing on earnings management and its economic consequence: Evidence from China. Asia-Pacific Journal of Accounting and Economics, 1(21), 1-21. https://doi.org/10.1080/16081625.2019 .1600414

Kang, S., \& Sivaramakrishnan, K. (1995). Issues in testing earnings management and an instrumental variable approach. Journal of Accounting Research, 33(2), 353367. https://doi.org/10.2307/2491492

Kao, J., Wu, D., \& Yang, Z. (2009). Regulations, earnings management, and post-IPO performance: The Chinese evidence. Journal of Banking and Finance, 33(1), 63-76. https://doi.org/10.1016/j.jbankfin.2007.03.016

Kinnunen, J., Keloharju, M., Kasanen, E., \& Niskanen, J. (2000). Earnings management and expected dividend increases around seasoned share issues: Evidence from Finland. Scandinavian Journal of Management, 16(2), 209-228. https://doi.org/ 10.1016/S0956-5221(99)00017-2

Ky Ngoc. (2020, January 2). VN Index khep lai nam 2019 voi muc tang 7,7\%, nam 2020 thi sao?. Forbes Vietnam. Retrieved 22 September 2020 from https://forbesvietnam.com.vn/tin-cap-nhat/vn-index-khep-lai-nam-2019-voi -muc-tang-77-nam-2020-thi-sao-8710.html

Lang, M., Raedy, J. S., \& Wilson. W. (2006). Earnings management and cross listing: Are reconciled earnings comparable to U.S. earnings? Journal of Accounting and Economics, 42(1), 255-283. https://doi.org/10.1016/j.jacceco.2006.04.005

Li, J., Zhang, L., \& Zhou, J. (2005). Earnings management and delisting risk: The case of IPO firms. Simon School Working Paper. FR 05-05. SSRN.com/abstract=641021.

Lin, J. -R. P. (2003). The long-run underperformance of post-listing stock returns: The evidence of earnings management. https://doi.org/10.2139/ssrn.341740

Mangala, D., \& Dhanda, M. (2019). Earnings management and performance of IPO firms: Evidence from India. Indian Journal of Corporate Governance, 12(1), 39-58. https://doi.org/10.1177/0974686219836542

McVay, S. (2006). Earnings management using classification shifting: An examination of core earnings and special items. The Accounting Review, 81(3), 501-531. https://doi.org/10.2308/accr.2006.81.3.501

Memis, M. U., \& Cetenak, E. H. (2012). Earnings management, audit quality and legal environment: An international comparison. International Journal of Economics and Financial Issues, 2(4), 460-469.

Ndubizu, G. A. (2007). Do cross-border listing firms manage earnings or seize a window of opportunity? The Accounting Review, 82(4), 1009-1030. https://doi.org/10 .2308/accr.2007.82.4.1009

New regulations on securities investment (2012). Vietnamlaw and Legal Forum Magazine. Retrieved 22 September 2020 from https://vietnamlawmagazine .vn/new-regulations-on-securities-investment-3966.html

Nguyen T. T., \& Ian, E. (2003). The Vietnam securities market. Securities markets, JASSA ISSUE 2, 36-40. Retrieved 29 May 2020 from https://www.finsia .com/docs/default-source/jassa-new/jassa-2003/2_2003_vietnam_securities .pdf?sfvrsn=e12bde93_6 
Nuryaman. (2013). The influence of earnings management on stock return and the role of audit quality as a moderating variable. International Journal of Trade, Economics and Finance, 73-78. https://doi.org/10.7763/IJTEF.2013.V4.263

Pastor-Llorca, M., \& Poveda, F. (2005). Earnings management as an explanation of the equity issue puzzle in the Spanish market. SSRN Electronic Journal. https://doi.org/10.2139/ssrn.880768

Premti, A. (2013). Earnings management prior to initial public offerings and its effect on firm performance: International evidence. International Journal of Financial Research, 4(3), 10-24. https://doi.org/10.5430/ijfr.v4n3p10

Qintao, F. (2007). Earnings management and ownership retention for initial public offering firms: Theory and evidence. The Accounting Review, 82(1), 27-64. https://doi.org/10.2308/accr.2007.82.1.27

Rangan, S. (1998). Earnings management and the performance of seasoned equity offerings. Journal of Financial Economics, 50(1), 101-122. https://doi.org/ 10.1016/S0304-405X(98)00033-6

Ronen, J., \& Yaari, V. (2008). Earnings management: Emerging insights in theory, practice, and research. New York: Springer.

Roosenboom, P., van der Goot, T., \& Mertens, G. (2003). Earnings management and initial public offerings: Evidence from the Netherlands. The International Journal of Accounting, 38(3), 243-266. https://doi.org/10.1016/S0020 -7063(03)00048-7

Roychowdhury, S. (2006). Earnings management through real activities manipulation. Journal of Accounting and Economics, 42(3), 335-370. https://doi.org/10.1016/ j.jacceco.2006.01.002

Sahlan, L. A. (2011). The Malaysian listing requirement reforms and earnings management practices of public listed firms. IUP Journal of Corporate Governance, 10(2), 1-32. https://doi.org/10.2139/ssrn.1635115

Shivakumar, L. (2000). Do firms mislead investors by overstating earnings before seasoned equity offerings? Journal of Accounting and Economics, 29(3), 339-371. https://doi.org/10.1016/S0165-4101(00)00026-4

Susana, C., José, I. J., \& David, W. (2017). Detecting earnings management investigation on different models measuring earnings management for emerging Eastern European countries. International Journal of Research, 5(11), 222-259. https://doi.org/10.29121/granthaalayah.v5.i11.2017.2351

Teoh, S., Welch, I., \& Wong, T. (1998a). Earnings management and the long-run market performance of initial public offerings. The Journal of Finance, 53(6), 19351974. https://doi.org/10.1111/0022-1082.00079

Teoh, S., Welch, I., \& Wong, T. (1998b). Earnings management and the underperformance of seasoned equity offerings. Journal of Financial Economics, 50(1), 63-99.

Vo, X. V., \& Phan, D. B. A. (2016). Herd behavior in emerging equity markets: Evidence from Vietnam. Asian Journal of Law and Economics, 7(3), 369-383. https://doi.org/10.1515/ajle-2016-0020

Zang, A., Y. (2012). Evidence on the trade-off between real activities manipulation and accrual-based earnings management. American Accounting Association, 87(2), 675-703. https://doi.org/10.2308/accr-10196 
Zhou, J., \& Elder, R. (2004). Audit quality and earnings management by seasoned equity offering firms. Asia-Pacific Journal of Accounting and Economics, 11(2), 95-120. https://doi.org/10.1080/16081625.2004.10510638

Zingales, L. (2009). The future of securities regulation. Journal of Accounting Research, 47(2), 391-425. https://doi.org/10.1111/j.1475-679X.2009.00331.x 